\title{
LEGISLATIVE TACTICS OF UNREGULATED LENDERS
}

\author{
JOHN KILGORE*
}

State legislative lobbies of unregulated lenders resort to tactics generally identical with those of a modern dictatorship waging a propaganda campaign against a neutral state selected for invasion. In each case efforts are made to confuse, to divert attention, to "soften up" the opposition and, to secure the assistance of agents within the victimized ranks.

Like Soviet Russia, nominating Finland as an aggressor, or like Nazi Germany, pretending fear of invasion from Poland, lobbies for unregulated lenders open a publicity campaign against licensed small loan companies in advance of a state legislative session at which an attempt to tighten the small loan laws is expected. With the aid of "scandal sheets" and sometimes with the aid of standard newspapers, the lobbyists inspire attacks upon licensed small loan companies as "loan sharks," "legalized racketeers," and " 42 percenters"-where that annual charge is allowed by law. This method of attack is carried on throughout the session by speakers before legislative committees, through newspaper advertisements and on the floors by members of legislative houses. Lobbyists and members of the legislature who have been won over to the side of the unlicensed lenders impugn the motives of legislators, editors, or bar association committeemen, who work against them, using the phrase "tools of the loan sharks," and similar epithets. When all else has failed, the last resort is to parliamentary delaying tactics, including the filibuster.

The purpose of such a campaign is manifold. The lobby hopes to attain one or more of these objects: to confuse the public and uninformed legislators; to discredit and embarrass disinterested crusaders against the racket; to prevent passage of the complete Uniform Small Loan Law or of an amendment to enlarge the scope of the existing law to cover salary buying or other lending dodges; to repeal the entire Uniform Law, if such a statute is on the books, as a method of eliminating competition from licensed lenders, or as a confusing counter-attack; to lower the rate licensed lenders are allowed to charge borrowers so that they can no longer do business and so that revenue of supervisory officials from license fees shall be inadequate to finance

- Managing editor, The Daily Democrat, Tallahassee, Florida. Newspaper writer in Georgia, North Carolina and Florida, since I921; editorial writer and political commentator on Florida newspapers, since 1925. Commissioned by Governor in $194^{\circ}$ as Director of Information, Education and Morale on Florida Defense Council. Conducted editorial campaign for regulation of unlicensed lenders during Florida legislative session 1939. Author, How a Few Florida Legislators Saved the 240\% Loan Shark Racket of the Salary Buyers (1940). 
investigation of lending practices; to maintain the status quo if legislation favorable to unlicensed lenders appears to be doomed or if legislation unfavorable to them appears to be nearing passage.

Lobbies organized to save unlicensed lenders from regulation are employed and financed by one or more of the half-dozen or so large interstate syndicates of highrate lenders. Policies of the several syndicates are surprisingly uniform in lending practices, as well as in lobbying tactics, which gives rise to the suspicion that they are organized into a trade association. Characteristics are: that the interest charge is uniformly $20 \%$ per month or $240 \%$ per year, that the lending practice is usually salary buying limited to camouflaged loans of from $\$ 5$ to $\$ 50$, that the legislative campaign in one state is practically a carbon copy of the campaign in another state, in which a supposedly rival syndicate is in control. Illegal or unlicensed lenders who charge greater than $240 \%$ a year-some more than $1,000 \%$ a year-are free lances who ride as stowaways with the big operators and who maintain no lobbies. The big syndicates, in fact, have been known to inspire local "Anti-Loan Shark" campaigns, closing their own doors during the excitement and reopening them as soon as the little chiselers, who conform to no standard rules, have been frightened away or locked up.

Syndicates, which finance lobbies, operate lending agencies that are illegal or within the law according to the status of small loan legislation and of court decisions in each state. The salary buying dodge, favorite with the syndicates, is not clearly illegal in states which have not adopted the Uniform Small Loan Law or in states which have adopted a small loan law without a section including salary buying as lending (Section 16 of the Uniform Law). In those states where court decisions hold that salary buying is not lending unless so defined by law, the syndicates can operate offices with little fear of prosecution or of regulation by state agencies. Advancing without investigation sums as small as $\$ 5$, in the hope usually of building up to a much larger sum, the sálary buyers enjoy a virtual monopoly of lending in the lower brackets and to the more ignorant classes of borrowers, and overlap in competition with licensed lenders usually on loans of from $\$ 20$ - the customary minimum licensed loan-to \$50.

A defective small loan law on the books enables the unlicensed lenders to diversify their legislative and propaganda campaigns with inspired attacks and smokescreens. The licensed small loan companies are blamed for all tragedies which have occurred to borrowers from all licensed and unlicensed lenders. Lurid stories are told and printed to illustrate what is claimed to be the result of permitting "legalized loan sharks" to operate-a favorite used in more than one state is the story of the suicide of a victim of a "legalized loan shark," presented through scare headlines in a cooperating scandal sheet newspaper. Many bills to amend the small loan law are introduced and advocated in committee and on the floor. Everything is done to confuse and to becloud the issue and to screen the position of the $240 \%$ lenders except to take a defensive position. Unlicensed lenders seldom try to defend high-rate prac- 
tices of any type but their lobbyists, when pressed, pretend to be impartially opposed to "both types of loan shark activities." They pretend therefore to be in favor of legislation to put all lenders under regulation and to reduce the small loan rate, assertedly in the interest of borrowers, but actually to a level which, in practice, is too low to maintain licensed loan offices, and therefore to the point where state regulation will fail for want of license revenue and borrowers without bank security will be at the mercy of unlicensed lenders.

While experience in certain other states is to the contrary, in Florida and some other states licensed lending companies exert little or no effective effort towards enlarging small loan legislation to cover unlicensed loan agencies. Legislative activities of licensed lenders are limited usually to a defense of the Uniform Small Loan Law and to maintenance of the status quo if the law on the books provides reasonable regulations and a rate section liberal enough to permit them to operate, even though a salary buying section may be absent.

Reasons for this limited activity are apparent. Licensed lenders have no competition from unlicensed lenders in the loan brackets which are profitable at legal small loan interest and little competition in the borrowing classes they find desirable. They fear the harmful effects of legislative "smear campaigns" upon their uphill fight to establish licensed lending in public esteem. They fear adverse effects which may be so serious as to put them out of business in the state if amendments, offered and advocated at the behest of lobbyists for the unlicensed lenders, should be adopted. They are disinclined to levy upon themselves-out of net earnings of 8 to $12 \%$ annually-assessments for lobbying funds which would be required to compete on equal terms with the expensively outfitted lobbies of the unlicensed lenders-financed out of gross income that may be as much as four times the capital invested. And they are handicapped by the opposition in state association conventions of licensed lenders who act as the Quislings of the 240 percenters. Many bona fide licensed lenders, therefore, argue that they and the state association should let well enough alone since they can do business under the law, as it is, and since they may be forced out of business if they should organize an expensive legislative fight with the unlicensed lenders and lose it. Most licensed lenders, however, cooperate with legal aid societies and others to improve loan laws and practices.

Licensed lenders, under such established policies, customarily are represented at legislatures by their retained attorney, who may have one or two assistants, and by one or two regularly employed observers sent to the scene to report activities to a large national company in the small loan field.

Unlicensed lenders build up a typical lobby around the figure of a veteran of politics and lobbying who is invariably an old resident of the state with a wide and useful acquaintance. The lobby is enlarged to at least a dozen by the employment of experienced lieutenants, contact men, and watchers. Members always include the most successful professional lobbyists, who have built reputations for proficiency at several consecutive sessions, representing often several interests at once for fees on 
a sliding scale based on the financial standing of the backers of bills and on the relative difficulty of assignments. The lobby also may contain one or more newspapermen on the fringe of respectability and, perhaps, one or more women with legislative contacts, whose job it is to listen and report.

Newspapers and legislators, friendly to unlicensed lenders, open up a barrage of criticism against attorneys or representatives of licensed lenders, nominating them "a large and vicious lobby of the legalized loan sharks," thus diverting attention from the larger professional lobby of the unlicensed lenders. This may serve the additional purpose of intimidating the representatives of the licensed lenders and of encouraging them to maintain silence and to avoid activities that might tread upon the toes of the 240 percenters.

As a result of this situation, an effective campaign against unlicensed lenders must be organized and financed by disinterested individuals or associations. In Florida, a group of young legislators-one of whom, Senator Spessard L. Holland, subsequently has been elected governor of the state-led the fight with little assistance except from The Daily Democrat, a capital newspaper. In Missouri, ${ }^{1}$ a committee coordinating efforts of labor unions and the bar associations of state and cities, spearheaded the drive against loan racketeering. In both cases, lobbyists and their legislative friends impugned the motives and cast slurs upon the honesty of the antiracketeer forces.

The Missouri campaign against unlicensed lenders was conducted with greater success than was the Florida campaign by reason of the superior organization behind the former. The prestige of the unions and bar associations which supported the Missouri campaign, with members on the legislative committee, added much weight to the cause. Additional help was forthcoming from the organizations as they carried on their activities throughout the state during the legislative session, thus placing pressure upon legislators who may have been weakening. The Florida campaign was rendered impotent through the lack of an organized committee at the session, the lack of organization work in the counties of the state, and the lack of even one man outside or within the legislative membership devoting full time or even half time to the activities against unlicensed lenders.

A weakness of both organizations was the relative youth and inexperience of most of those who were combating at the sessions the activities of the large, full-time lobbies of the unlicensed lenders. The youthful complexion of forces gathered to combat unlicensed lending is doubtless due, on the one hand, to the willingness of young attorneys and others to win their spurs in thankless and even somewhat dangerous undertakings, or to their undimmed enthusiasm and idealism; and on the other, to the unwillingness of seasoned attorneys and veteran businessmen, with profitable practices or businesses, and with many demands upon their time, to undertake a public service which calls for self-sacrifice and invites public abuse without

\footnotetext{
'Gisler, What Bar Associations Did in Missouri to Combat the Loan Shark Evil, Program and Papers (Conference Personal Finance Law, 1939) 36.
} 
even the compensation of financial reward. Capable, experienced men participated in the fight against loan racketeering, but legislators-in Florida, at least-were forced to divide their time and their energies among several important and exacting duties, and not one was able to keep a close watch upon the lobbyists in order to be able to anticipate their moves.

A near-perfect organization to combat a lobby for unlicensed lenders would include enthusiastic young attorneys but would be headed by a fearless, seasoned, hardhitting criminal lawyer or retired legislative veteran-say, a man like the late Clarence Darrow-with no other pressing duties and with a consuming desire to cap his career with a great, unselfish act in the public service. Such a legislative committee might consist of no more than six men, one of whom should be a veteran political reporter backed by a courageous, independent daily newspaper of wide circulation. The legislative committee should represent and should have the active support in the several counties of bar associations, labor unions, business and credit associations, civic clubs and women's organizations. Before the opening of a legislative session and during the legislative battle there should be a relentless campaign of education and publicity throughout the state with special attention to members of the legislature. As Mr. Gisler has pointed out in his article in this symposium the strongest weapon of enemies of loan racketeering is factual data, since experience shows that honest men are easily convinced when they have had the purpose and meaning of the Uniform Small Loan Law explained to them in a way they can understand. Adequate publicity and education, therefore, narrow the opposition to those who have been trapped into pledges of support and to the dishonest-a minority in all instances. Time would be the only other vital factor in the success of a campaign so organized. Sufficient pressure must be applied early in a legislative session to bring the issue to a final conclusion or friends of the "high raters" in the legislative houses will delay action until too late and will filibuster at the end of the session, if necessary.

It is necessary that a legislative committee, organized for such a purpose, understand fully that a fight against unlicensed lenders is difficult, exacting, and fraught with peril. No one who shrinks from criticism or who is unwilling to swap verbal punches with ruthless and clever men should undertake the task. No holds are barred and no quarter is given or asked in the course of such a fight but the weapons are never more lethal than the printed or spoken word. Unlicensed high-rate lenders who support lobbies are ruthless in many respects but they are not gangsters-the same caution which leads them to limit their gouging interest to $240 \%$ a year, while the "small fry" charge $x, 000 \%$ or more, inclines them against strong-arm tactics.

The chief danger to the success of a campaign against unlicensed lenders lies in the overconfidence of proponents-particularly men advocating remedial legislation who have had some experience in guiding bills through legislative bodies. Such men recall the relative ease with which legislative action was secured on less meritorious bills and assume that there will be no difficulty in securing passage of the complete 
Uniform Small Loan Law. In South Carolina in I940, for example, support at the hearings for an adequate small loan law was given on behalf of such groups as the Cotton Manufacturers Association, the American Federation of Labor, the bar associations, and the associated women's clubs. One might have been justified in assuming quick passage of a bill with such backing, but it failed as have all other attempts in South Carolina. Veterans of other anti-loan shark campaigns may argue for hours without convincing the proponents that such campaigns often fail for mysterious reasons and that what seems, on its face, to be so easy, actually is one of the most difficult of all legislative assignments. Often the lobbyists for unlicensed lenders play dead so as to encourage the notion that there is no difficulty in store for the measure. These tactics reassure the proponents through several disappointing but apparently unavoidable delays.

When strong pressure is applied, the lobbyists come out of hiding far enough to scotch the legislation and when the "heat is turned on" they go into full action. Many strange things begin to happen. Committee members expected at hearings are inexplicably missing so that quorums are not obtained. Expected action is deferred or talked past adjournment time. The bill is pigeon-holed in committee or sent back to committee from the floor. Other measures in which many members are kzenly interested are set ahead of the remedial measure on calendars. When the remedial bill is about to be reached on the calendar, unexpectedly long debate occurs on other measures. Trades are made undercover with ardent proponents of other bills to secure further postponement of action on the remedial measure. Political sup. port in future elections is offered for deferment or for votes against the remedial bill. These and many other things plague the days of legislative committeemen working to control the loan rackets, and contribute to their sleepless nights. Alert, tireless watchfulness and energetic, competent effort day after day, are called for if success is to be expected.

A brief review of the legislative tactics of the Florida lobby for unlicensed lenders -typical of such tactics elsewhere-will provide a specific example of the type of campaign that may be expected anywhere, although new devices may be invented or modifications adopted as occasions require to protect $240 \%$ lending syndicates. From the opening of Florida's 1939 legislative session, desks of members were circulated with free copies of a daily newspaper and of a weekly tabloid published elsewhere. These newspapers contained editorial and political column attacks upon the licensed lending companies and such items as the headlined suicide of the supposed victim of a legalized loan shark, with the inference that he had taken his life to escape the toils of a licensed lender. Editorial attacks were diversified and designed to appeal to prejudices. Records in the Florida comptroller's office show that chain lending companies have 7 of the state's 77 licensed loan outlets, but these outof-state chains were made the targets of attacks so worded that the reader was led to believe that licensed lending in Florida was carried on exclusively by outsiders, waxing rich in northern cities. Appeals, on behalf of the "Florida Crackers," were 
made to stir up prejudice against officials of chain lending firms who receive large salaries, and-verbally-against Jews. This last appeal is particularly strange in view of well authenticated information that members of this race do not control the large lending chains that were under attack. ${ }^{2}$ The criticism was phrased in broad general terms with careful avoidance of accurate figures or reference to net earnings. For example, it was stated with constant repetition that the northern chains were draining "thousands and thousands" or "millions and millions" of dollars out of the state, extracted from the poor. Pleas were made for reductions in the lawful charges by licensed lenders, always without citation of any authority to sustain a recommended rate less than that allowed by the Uniform Small Loan Law.

Near mid-session, advertisements, originally published in Jacksonville newspapers, over the signature of the Morris Plan Bank of Jacksonville, Tallahassee, and St. Augustine, were republished in Tallahassee newspapers. One of these Tallahassee advertisements was entered first as "paid for by Florida Citizens interested in the welfare and progress of Florida and her people," and a second time over the signature of the self-admitted chief lobbyist of the salary buyers. There are two unique factors in this transaction. The attack upon the Uniform Small Loan Law by the Jacksonville Morris Plan Bank ${ }^{3}$ is the only case that has come to the attention of the writer, through experience, report or study of accounts of legislative battles in other states, in which a legitimate business has apparently given aid or comfort to the unlicensed lenders. And the admission of the chief lobbyist of the salary buyers at Florida's 1939 session that he was serving the interests of unlicensed lenders is the only case that has come to notice in which such lobbyists did not adhere throughout the sessions to the claim that they were representing only themselves as public benefactors or citizens interested in the welfare of the state.

These sample advertisements and a typical editorial expression illustrate the publicity build-up sought by an unlicensed lenders' lobby.

The first advertisement, that of April 27, follows:

\section{LEGISLATORS-LOOK!}

\section{Lending Money at High Rates Is No Help to Any Community \\ PENALIZING \\ FLORIDA CRACKERS ${ }^{4}$}

In Tennessee the Gum Bedstead Loan Company was forced to reduce its interest rate from $3 \frac{1}{2}$ per cent to $1 \frac{1}{4}$ per cent-thanks to the Tennessee Legislature.

In Georgia the Gum Bedstead Loan Company was forced to reduce its interest rate from $3 \frac{1 / 2}{2}$ per cent per month to $1 \frac{1}{2}$ per cent-thanks to the Georgia Legislature.

\footnotetext{
2 Time, March 23, I931, p. 51.

a Morris Plan banks are, of course, local lending businesses, not to be confused with chain organizations under central ownership and policy control, as is generally but erroneously assumed.

-This peculiar plea for the Florida Crackers sounded by the Jacksonville Morris Plan Bank apparently on behalf of borrowers and repeated as a sort of refrain by lobbyists for the "cracker" salary" buyers is one of the strangest angles of a strange legislative fight. All the evidence available indicates that it is
} 
In Florida the Gum Bedstead Loan Company still charges distressed householders $3 \frac{1}{2}$ per cent per month-THANKS to the FLORIDA LEGISLATURE.

Our Bank has no furniture loans, no Wage Assignments and makes no attempt to keep borrowers continuously in debt, hence is not a competitor of chattel lenders.

We co-operate with merchants and credit bureaus, but profess no philanthropy and claim no generosity in our own discounts-which, based upon amount and character of loan, vary from ten to six per cent per annuin. This is enough for any man to pay.

\section{MORRIS PLAN SAVINGS BANK Jacksonville}

\section{St. Augustine \\ Tallahassee}

The reading matter in the above advertisement was carried in a 2 column by 8 inch advertisement in the Florida Times-Union of April 26, and is reproduced here, and paid for by Florida Citizens, interested in the welfare and progress of Florida and her people.

The second advertisement, which appeared in two newspapers, follows:

\section{LEGISLATORS ! ! !}

Let's Outlaw the 42 Percenters and Protect Florida's POOR PEOPLEl

\section{THE 42 PERCENTERS}

are taking millions upon millions of dollars in money each year from the people-POOR people who are forced to go to them for loans-of this state.

\section{THE 42 PERCENTERS}

sncer at honest Florida business men and bankers as they draw helpless victims into their net, and strangle them for interest payments at the rate of $3 \frac{1}{2}$ per cent per month, secured by a poor man's most cherished possessions-his family, household and kitchen furniture.

\section{THE 42 PERCENTERS}

don't believe in Florida development or progress; all they want is to get the money of our POOR people, and send it to their NORTHERN OVERLORDS.

\section{THE FLORIDA LEGISLATURE}

has carelessly and inhumanely permitted the 42 percenters to continue their depredations on the poor.

\section{LET'S OUTLAW THEM}

Let's set a decent, humane interest rate for rich and poor alike.

This advertisement is paid for by friends of Florida progress and and Florida develop. ment.

characteristic of salary buyers that they operatc in states other than those in which their headquarters are located and in which their owners live: "That six different companies have flourished for years in downtown Tampa doing this type of business exclusively gives you an idea. They are Flagler \& $C_{0}$., Davis-Warner Co., Mansficld and Harrington, Banks \& Company, Gibson \& Company, and Walker \& Company. (In no case has any person becn found with the same nane as the conipany). Alt six are owned and controlled by capital and persons outside the state. Hence only employes here could be indicted. Atlanta scems to be headquarters with Memphis a close second." Marchant, Salary Buying in Florida (1939) 11, quoting Statc's Attorney Farrior of Hillsbornugh County. Sec alsn Collins, Evasion and Avoidance of Ustiry Laws, supra p. 54, at 69. 
A characteristic editorial expression in line with the tactics of unlicensed lenders is reproduced from a newspaper circulated free to legislators during the session:

"The 'halt-way' regulation bill for small loan operators has been reported unfavorably, as it should have been, by the senate banks and loans committee. By this bill, reference is made to the bill that puts Salary Buyers under the vicious 1925 small loan law, but which continues to allow everyone licensed to make small loans to charge enormous 42 per cent interest rates.

"Regulating one group of high-interest lenders to meet the demands of a competing group, particularly when the latter is composed in entirety of northern loan sharks who are making this bold attempt to take over all the small loan business in Florida, is no way to abolish the high interest evil."

Lobbyists continued such attacks before committees of the two houses and members of the legislative bodies introduced and pressed for favorable action on a variety of bills which would have had the effect of emasculating the Florida version of the Uniform Small Loan Law-intact except for the omission of a salary buying section, and some other slight modifications. Nevertheless, the house of representatives rejected overwhelmingly a series of amendments proposed on the floor by two representatives, and passed unanimously a remedial bill to restore the missing section which defines salary buying as lending. Even the two representatives who advocated the emasculating amendments voted for the remedial bill on final roll call.

This complete victory in one house contributed to the subsequent disaster in that it convinced proponents of the remedial bill that the opposition was impotent and that little more effort was required. But on the senate front there was more action. The chief lobbyist of the unlicensed lenders engaged the writer in a newspaper duel, during which he purchased advertising by the page in a local daily newspaper to answer editorial and political column attacks-and to counter attack. The chief lobbyist was present and harangued senate committees while the remedial and other small loan bills were under consideration. A house member attacked the motives of the writer on the floor. The senate banking committee put one remedial bill on the calendar without reference on a tie vote and rejected a similar bill by the margin of one proxy vote. Efforts to secure favorable calendar status from the senate rules committee for the surviving bill were apparently successful but failed under pressure from senators friendly with the lobbyists. Motives of a state senator, now governor, a proponent of remedial legislation, were sarcastically questioned by another senator who later filibustered against regulation of salary buyers.

The writer collaborated with senate and house advocates of remedial legislation in a parliamentary maneuver which slipped an apparently innocuous senate local bill through the house, amended to make it a general bill, and back into the senate with mandatory preferred status, in the final days of the session. This called the lobby into full cry and threw the senate into bedlam. In the ensuing excitement, there was a scuffle on the floor in which one senator struck another with his cane and a filibuster was hastily organized which threatened to kill hundreds of important 
measures caught between the two houses. On the last night of the session, with the filibusterers committed to carry on until the end, proponents of the remedial bill were forced to capitulate to save many important measures that would have died for want of final disposition.

In the fight at Florida's 1939 legislative session the tactics of the unlicensed lenders failed down to the final round. The smoke screen and counter attack propaganda was rendered ineffectual. But the final recourse of unlicensed lenders-political protection on the inside-was effective and defeated efforts to secure remedial legislation. The big flaw in the Florida campaign to regulate and license all small lenders was in timing-an earlier showdown in the senate would have cancelled the effectiveness of a last-minute filibuster.

This is the type of opposition that any volunteers anywhere may expect when they enter the lists against unlicensed lenders: They may expect to deliver hard work and to receive invective and abuse from cynical masters of venomous rhetoric-and very little else except the satisfaction of doing a job. It is no game for the fainthearted. 